\title{
ANALISIS TINGKAT KERUGIAN KEHILANGAN AIR PADA PROSES DISTRIBUSI SPAM UNS
}

\author{
Enggar Wahyu Wulaningtyas ${ }^{1}$, Ferry Dimas Prakoso ${ }^{2}$, Meidi Putri Ariyani ${ }^{3}$, Muhammad Iriandru \\ Pradipta $^{4}$, Yuniaristanto ${ }^{5}$, dan Wahyudi Sutopo ${ }^{6 *}$
}

1,2,3,4,5,6Program Studi Teknik Industri, Fakultas Teknik, Universitas Sebelas Maret

Jl. Ir. Sutami 36A, Surakarta, 57126, Indonesia

*email: wahyudisutopo@staff.uns.ac.id

\begin{abstract}
As time goes by, there are more problems regarding the quantity and quality of water in Indonesia. One of these problems was found at Sebelas Maret University (UNS), precisely at Sistem Penyediaan Air Minum UNS (SPAM UNS). In serving its customers, SPAM UNS provides water tap and water dispenser facilities. However, there are still many weaknesses in the distribution of water. This is due to the frequent occurrence of pipe leaks and it takes a long time to find the location of the leak. As a result, financial losses experienced are quite large. The purpose of this study is to reduce losses by using the District Meter Area (DMA) concept to determine the area coverage (zoning) and the Analytical Hierarchy Process (AHP) method to determine the location of new reservoirs as a follow up of the zoning system. By implementing the DMA concept and the AHP method, SPAM UNS is able to reduce financial losses. The results obtained are making a new reservoir feasible because the value of the construction is almost the same as the initial loss value experienced by the UNS SPAM distribution network.
\end{abstract}

Keywords: Analytical Hierarchy Process, District Meter Area, Water Loss, Reservoir, SPAM

\section{Pendahuluan}

Dalam menjalankan berbagai aktivitas, seperti minum, mandi, mencuci, ataupun hal lainnya, manusia membutuhkan air. Dari aktivitas-aktivitas yang telah disebutkan, keperluan utama dari manusia adalah air minum. Namun, perlahanlahan banyak terjadi masalah mengenai ketersediaan air minum, seperti kualitas, kuantitas dan kontinuitas dari air minum tersebut (Kusumajati, Solichin, \& Koosdayani, 2016).

Universitas Sebelas Maret (UNS) merupakan salah satu perguruan tinggi yang memiliki fasilitas penyedia air minum, yaitu Sistem Penyediaan Air Minum (SPAM) UNS yang merupakan salah satu program dari UNS Green Campus. SPAM UNS memiliki beberapa produk, antara lain kemasan botol dan galon dengan merek UNSQua, serta water tap dan water dispenser. Untuk produk kemasan botol dan galon masih bersifat berbayar, namun penjualan masih dalam cakupan internal UNS. Sedangkan, untuk water tap dan water dispenser bersifat gratis, dimana fasilitas ini tersedia menyebar di 129 titik dalam berbagai fakultas, serta gedung-gedung lainnya di UNS. Pendistribusian air ke water tap atau water dispenser di berbagai tempat adalah dengan melalui pipa. SPAM UNS memproduksi air selama 2 hari sekali dengan kapasitas setiap produksinya adalah 28.500 liter setiap pengolahan.

Sumber air yang dimanfaatkan oleh SPAM UNS berasal dari deepwell pada area stadion kampus. Air dipompa dari deepweell kemudian melalui pengolahan dengan menggunakan teknologi ultrafiltration (UF) dipompa naik ke reservoir setinggi $20 \mathrm{~m}$ untuk didistribusikan ke seluruh kampus dengan sistem gravitasi. Sistem gravitasi ini diharapkan dapat mengoptimalkan pengoperasian distribusi air minum tanpa harus mengoperasikan pompa air. Untuk pengoperasiannya, SPAM UNS menggunakan listrik dari solar cell dengan kapasitas $20 \mathrm{kVA}$. Distribusi air minum dialirkan melalui sistem loop utama dan dicabangkan ke water tap dan water dispenser yang ada tersebar di berbagai fakultas maupun gedung-gedung lainnya di UNS (Kusumajati, Solichin, \& Koosdayani, 2016).

Dengan sistem pendistribusian seperti yang telah disebutkan, SPAM UNS memiliki target untuk dapat mendistribusikan air dengan kuantitas dan kualitas yang baik. Namun kenyataannya, untuk mendistribusikan air sesuai dengan yang diinginkan masih banyak kendala yang dialami, 
seperti kebocoran pipa dan kualitas air. Masalah kebocoran pipa menjadi perhatian utama pada SPAM UNS dikarenakan hal ini menyebabkan kehilangan air yang menghasilkan kerugian cukup besar bagi SPAM UNS. Ditambah lagi kebocoran pipa yang terjadi tidak dapat dideteksi lokasinya pada sistem sehingga perlu dilakukan peninjauan di seluruh titik sehingga memakan waktu yang lama (kurang lebih 2 hari) dan menghasilkan kerugian yang makin besar. Menurut Febriany (2014), kehilangan air merupakan salah satu permasalahan yang selalu terjadi di setiap pendistribusian air melalui pipa yang penyebab utamanya adalah kebocoran. Faktor dari kebocoran itu sendiri dapat dibagi menjadi dua macam, yaitu faktor kebocoran teknis dan faktor kebocoran non teknis (PDAM, 2012). Faktor kebocoran teknis pada sistem distribusi sulit untuk dilakukan karena kebocoran bersifat insidentil atau tidak dapat direncanakan. Namun, untuk mengatasi hal tersebut masih dapat dilakukan analisis berdasarkan tekanan dengan lamanya waktu kebocoran yang terjadi, sehingga dapat diperoleh suatu strategi untuk menekan jumlah kerugian dari kebocoran yang terjadi. Maka diperlukan upaya perbaikan mekanisme perencanaan, pelaksanaan, dan pengendalian program distribusi.

Salah satu sistem yang digunakan untuk mengontrol kebocoran air adalah District Meter Area (DMA), yaitu suatu sistem yang digunakan untuk mendeteksi kebocoran yang tidak tampak, dengan membentuk suatu wilayah pengaliran dengan menempatkan meter induk di setiap pengaliran (Andayani, Firda, \& Permatasari, 2019). Maka untuk menyelesaikan kasus tersebut digunakan konsep dari DMA, dimana penggunaan konsep DMA sesuai dengan kebutuhan SPAM UNS dimana kebocoran dapat dideteksi lebih mudah karena akan dilakukan penempatan meteran di setiap pengaliran dan penzonaan sehingga lingkup yang dideteksi lebih kecil dan memakan waktu yang lebih kecil, serta menekan kerugian yang ada. Penzonaan ini juga akan berpengaruh pada jumlah reservoir yang digunakan, jumlah reservoir bergantung pada jumlah zona yang akan ditetapkan. Selain itu, perlu digunakan Metode Analytical Hierarchy Process (AHP) mengenai lokasi penempatan reservoir tambahan hasil dari penzonaan yang dilakukan agar kerugian yang diakibatkan dari waktu pencarian lokasi dari kebocoran bisa diminimalisir sebaik mungkin. Menurut Fatchurahman (2016), Metode AHP adalah sebuah metode yag digunakan untuk memecahkan permasalahan yang kompeks atau rumit dalam situasi yang tidak terstruktur menjadi bagian komponen-komponen.

\section{Landasan Teori}

\subsection{Analitical Hiarchy Process (AHP)}

AHP merupakan salah satu metode perbandingan berpasangan yang paling populer digunakan untuk pengambilan keputusan dalam permasalahan Multi-Criteria Decision Making (MCDM). Pendekatan AHP didesain untuk membantu pengambil keputusan untuk menggabungkan faktor kualitatif dan faktor kuantitatif dari suatu permasalahan yang kompleks. Penggunaan AHP dalam berbagai bidang meningkat cukup signifikan, hal ini dikarenakan AHP dapat menghasilkan solusi dari berbagai faktor yang saling bertentangan. AHP diaplikasikan dalam bidang agrikultur, sosiologi, industri dan lain sebagainya. Prinsip kerja AHP adalah membentuk suatu struktur permasalahan.

Dalam menyelesaikan permasalahan MCDM, AHP menyusun struktur hirarki masalah mulai dari yang paling atas yang disebut goal, kemudian dibawahnya disebut variabel kriteria dan selanjutnya diikuti oleh variabel alternatif. Pengambil keputusan, selanjutnya memberikan penilaian numerik berdasarkan pertimbangan subjektifitas terhadap variabel-variabel yang ada untuk menentukan tingkatan prioritas masingmasing variabel tersebut (Walangare, Delima, \& Restyandito, 2012).

Dalam menggunakan metode AHP, dilakukan pengumpulan data melalui kuesioner terhadap lima orang staf SPAM UNS, yang berasal dari divisi maintenance, produksi, quality control, infrastruktur, pengiriman, maupun koordinator administrasi. Setelah diperoleh data kuesioner, dilakukan pengolahan data yang telah diperoleh dengan bantuan software Excel 2016 sehingga didapatkan bobot untuk setiap alternatif tempat reservoir berdasarkan kriteria-kriteria yang sudah ditetukan. Alternatif tempat yang dipilih adalah alternatif yang memiliki bobot paling banyak.

\subsection{Perhitungan persen kehilangan}

Perhitungan persen kehilangan dapat dilakukan dengan persamaan (1). Menurut Siregar dan Mulia (2013), Tingkat kehilangan air dihitung persentasenya berdasarkan selisih antara jumlah air yang didistribusikan (m3). Lalu, dilakukan perhitungan biaya kerugian (kehilangan finansial) perusahaan, yaitu perkalian antara tarif rata-rata dari air minum dengan jumlah kehilangan air yang ditunjukkan pada persamaan 2 (Puspitasari \& Purnomo, 2017). 


\subsection{Pendekatan DMA}

Prinsip pendekatan dari DMA sendiri adalah pembagian jaringan perpipaan distribusi menjadi zona-zona hidrolik kecil-kecil dan pengukuran tekanan dan aliran secara berkelanjutan untuk mengetahu kebocoran pipa dan memperbaikinya. Sementara itu manfaat yang dapat diperoleh dengan pembentukan DMA antara lain adalah untuk prioritasi kegiatan deteksi kebocoran, pengaturan tekanan yang ideal, dan berguna untuk perbaikan kualitas air dan pelayanan (PUPR, 2018).

\subsection{Reservoir}

Fungsi dari reservoir itu sendiri adalah untuk menyeimbangkan antara debit produksi dan debit pemakaian air yang berfluktuasi selama 24 jam. Dan dalam sistem distribusi, berdasarkan fungsinya, reservoir dibagi menjadi dua kategori, yaitu reservoir pelayanan dan reservoir penyeimbang. Reservoir yang diusulkan pembagunannya adalah reservoir pelayanan yang memiliki fungsi sebagai pemasok sebagian besar jaringan pipa distribusi; untuk menambah tekanan air pada jaringan pipa distribusi; agar tekanan air pada jaringan pipa distribusi relatif stabil; sebagai tempat persediaan air pada keadaan darurat, yaitu saat terjadi kebakaran,atau pipa transmisi sedang diperbaiki atau saat pompa untuk mengisi reservoir jalan dan untuk kepentingan umum lainnya; sebagai tempat pencampuran air dengan desinfektan, sehingga pencampuran lebih merata, disamping itu dengan pencampuran lebih lama diharapkan sisa khlor yang berlebih dapat dikurangi; dan sebagai tempat pengendapan pasir atau kotoran lain, yang mungkin masih terbawa air dari instalasi pengolahan atau dari sumur dalam (BSN, 2011).

\section{Metode Penelitian}

Metode penelitian yang digunakan dalam upaya meminimalisir kehilangan air pada distribusi air SPAM dilakukan dengan beberapa tahap seperti pada gambar 1 berikut ini.

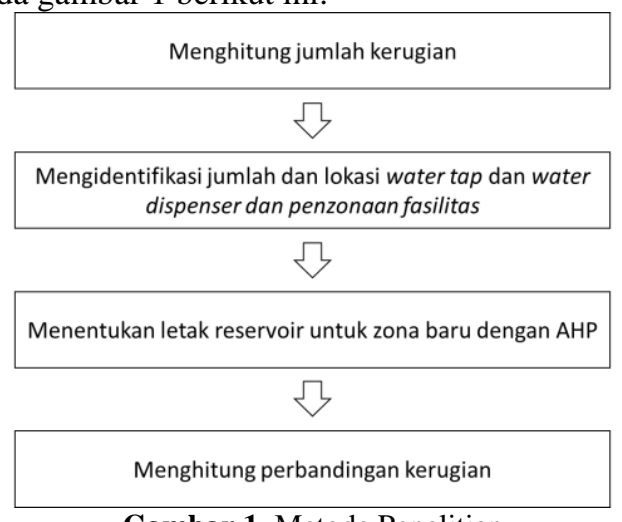

Gambar 1. Metode Penelitian
Tahap pertama adalah menghitung jumlah kerugian yang dihasilkan dari kehilangan air akibat kebocoran pipa selama kurun waktu setahun. Tahap kedua adalah melakukan identifikasi jumlah dan lokasi dari setiap fasilitas water tap dan water dispenser berdasarkan data yang diambil pada 16 Desember 2019, serta melakukan penzonaan untuk fasilitas-fasilitas tersebut dengan konsep dari DMA. Tahap ketiga adalah menentukan letak reservoir untuk zona baru dengan menggunakan metode AHP.

Tahap keempat adalah menghitung perbandingan kerugian sebelum dan setelah adanya penzonaan, hal ini dilakukan dengan persamaan (1) dan (2) sama seperti tahap pertama. Selain itu, dilakukan perhitungan pembuatan Rancangan Anggaran Biaya (RAB) yang digunakan untuk membangun reservoir baru. Berikut persamaan matematik yang digunakan dalam penelitian ini:

1. Kehilangan Air

Untuk menghitung besar atau persen dari kehilangan air dapat dihitung berdasarkan rumus (Thornton,2008):

$H=\frac{D-K}{D} \times 100 \%$

Dimana $\mathrm{H}=$ kehilangan $(\%), \mathrm{D}=$ jumlah air yang didistribusikan $\left(\mathrm{m}^{3}\right), \mathrm{K}=\mathrm{jumlah}$ air yang dalam rekening tagihan $\left(\mathrm{m}^{3}\right)$.

2. Kerugian Finansial

Untuk menghitung besarnya nila kehilangan finansial atau biaya kerugian dari perusahaan dalam kurun waktu sebulan dapat dihitung berdasarkan persamaan:

Kerugian Finansial $=n \times$ Tarif rata rata per bulan (Rp per $m 3$ ) $x$ Total Kehilangan (2)

Dimana $\mathrm{n}=$ frekuensi terjadinya kebocoran dalam sebulan

\section{Hasil dan Pembahasan}

Berikut ini merupakan hasil dan pembahasan yang diperoleh dari seluruh tahapan yang dilakukan oleh peneliti dalam penelitian ini.

\subsection{Perhitungan Jumlah Kerugian}

Perhitungan dilakukan dengan menghitung jumlah kehilangan air pada setiap kebocoran yang terjadi dan menghitung jumlah kerugian yang dikeluarkan oleh SPAM UNS. Kebocoran pada SPAM UNS diasumsikan terjadi sekali setiap bulannya. Untuk setiap kapasitas satu kali produksi, yaitu 28.500 liter, dari hasil wawancara oleh staff SPAM UNS dapat diketahui jumlah kehilangan air dapat mencapai 20.000 liter dalam satu kali kebocoran. Persentase kehilangan air dapat dihitung melalui persamaan 1 , karena nilai 
kehilangan air (D-K) sudah diketahui, yaitu 20.000 liter maka persentasenya adalah:

$H=\frac{D-K}{D} \times 100 \%$

$H=\frac{20.000}{28.500} \times 100 \%=70,18 \%$

Dari perhitungan tersebut diketahui bahwa kehilangan air mencapai persentase yang sangat besar karena sudah melebihi $50 \%$ sehingga akan menyebabkan kerugian yang cukup besar tentunya. Untuk mengetahui kerugian finansial maka diasumsikan bahwa harga 1 liter air adalah Rp 2.000,00 dan menurut hasil wawancara dapat diketahui bahwa frekuensi terjadinya kebocoran adalah sekali dalam sebulan, maka kerugian biaya yang dialami perusahaan selama sebulan adalah:

$\mathrm{X}=\mathrm{n} \times \mathrm{P} \times \mathrm{R}$

$X=1 \times \operatorname{Rp} 2.000 .000 \times 20.000$ liter

$\mathrm{X}=\mathrm{Rp} 40.000 .000$

Kerugian Finansial $=R p 40.000 .000,00$

Keterangan:

$\mathrm{X}=$ Kerugian Finansial

$\mathrm{n}=$ Jumlah

$\mathrm{P}=$ Tarif rata-rata per bulan $\left(\mathrm{Rp}\right.$ per $\left.\mathrm{m}^{3}\right)$

$\mathrm{R}=$ Total kehilangan (liter)

Dari perhitungan tersebut diketahui bahwa kerugian yang dialami perusahaan sangat besar apabila walaupun harga air minum tersebut gratis namun sebenarnya air tersebut dapat dialokasikan untuk produk kemasan jika dibandingkan terbuang sia-sia.

\subsection{Identifikasi Jumlah Fasilitas Penyedia Air Minum dan Penzonaan}

SPAM UNS memiliki 129 fasilitas penyedia air minum gratis, yaitu 69 water tap dan 39 water dispenser yang tersebar diseluruh fakultas maupun gedung-gedung lainnya di UNS. Untuk mempermudah pemantauan dan penangan kebocoran maka dilakukan zoning pada sistem pelayanan reservoir, di UNS sendiri hanya dibagi menjadi 2 zona pelayanan karena wilayah tidak terlalu luas dan apabila terlalu banyak reservoir yang ditambah maka biaya investasi yang perlu dikeluarkan juga semakin besar. Penentuan batas wilayah zona dilakukan sesuai dengan batas wilayah per fakultas sehingga memudahkan dalam pengontrolan. Pada lampiran 1 menunjukkan pembagian zona reservoir pelayanan. Dalam tabel pada lampiran 1 terdapat keterangan WT ataupun D di setiap akhir bangunan. WT menunjukkan fasilitas water tap, sedangkan D menunjukkan fasilitas water dispenser.

\subsection{Penentuan Letak Reservoir}

Penentuan letak reservoir diperuntukkan terhadap zona 2, dimana dibutuhkan reservoir baru untuk mempermudah dalam pemantauan dan penanganan kebocoran pipa di SPAM UNS. Metode yang digunakan untuk memilih lokasi reservoir itu sendiri adalah Metode Analytical Hierarchy Process (AHP). Menurut El Ahmady \& Emenda (2014), Metode AHP sendiri digunakan untuk memilih alternatif dan sub-alternatif program karena AHP dapat mengidentifikasi gagasan-gagasan untuk mencapai suatu tujuan utama sampai gugusan yang kecil dan terkecil dari suatu permasalahan, mencakup faktor kuantitatif dan kualitatif secara serentak, sehingga semua informasi terekam dalam struktur masalah yang lengkap. Menurut BSN (2011), berikut ini merupakan hal-hal yang harus dipertimbangan dalam pembangunan fasilitas reservoir:

1. Reservoir penyeimbang biasanya dibangun di dekat instalasi pengolahan air;

2. Reservoir pelayanan ditempatkan sedekat mungkin dengan pusat daerah pelayanan, kecuali kalau keadaan tidak memungkinkan selain itu harus dipertimbangkan pemasangan pipa paralel;

3. Ketinggian reservoir pada sistem gravitasi ditentukan sedemikian rupa sehingga tekanan minimum sesuai hasil perhitungan hidrolis di jaringan pipa distribusi primer adalah $15 \mathrm{~m}$.

4. Muka air reservoir rencana diperhitungkan berdasarkan tinggi muka air minimum;

5. Jika elevasi muka tanah wilayah pelayanan bervariasi maka wilayah pelayanan dapat dibagi menjadi beberapa zone wilayah pelayanan yang dilayani masing-masing dengan satu reservoir.

Dari keterangan yang telah disebutkan di atas maka AHP untuk penentuan lokasi reservoir tambahan dapat dilihat pada lampiran 2 . Sedangkan untuk pembobotan dari masing-masing kriteria adalah sebagaimana ditunjukkan pada tabel 1 .

Tabel 1. Prioritas Kriteria

\begin{tabular}{lcccccc}
\hline \multirow{2}{*}{ Kriteria } & $\mathbf{1}$ & $\mathbf{2}$ & $\mathbf{3}$ & $\mathbf{4}$ & $\mathbf{5}$ & $\begin{array}{c}\text { Rata- } \\
\text { rata }\end{array}$ \\
\cline { 2 - 7 } & 0.070 & 0.089 & 0.119 & 0.098 & 0.085 & 0.081 \\
\hline $\begin{array}{l}\text { Jarak } \\
\text { dengan } \\
\text { instalasi air }\end{array}$ & 0.083 & 0.090 & 0.062 & 0.298 & 0.084 & 0.119 \\
\hline $\begin{array}{l}\text { Jarak } \\
\text { dengan } \\
\text { pusat } \\
\text { pelayanan }\end{array}$ & 0.356 & 0.422 & 0.449 & 0.210 & 0.233 & 0.334 \\
\hline $\begin{array}{l}\text { Ketinggian } \\
\text { tempat }\end{array}$ & 0.185 & 0.122 & 0.083 & 0.118 & 0.292 & 0.160 \\
\hline $\begin{array}{l}\text { Ketersediaan } \\
\text { lahan }\end{array}$ & & & & & & \\
\hline
\end{tabular}


Dari tabel 1 dapat diketahui bahwa prioritas utama menurut kelima responden dari pembuatan reservoir adalah ketinggian lokasi dengan nilai bobot rata-rata terbesar, yaitu 0,481. Hal ini disebabkan karenareservoir membutuhkan lokasi tempat yang tinggi, sebab reservoir menggunakan bantuan sistem gravitasi dalam proses pendistribusian air sehingga hanya memerlukan tekanan yang minimum. Untuk kriteria jarak, baik dengan pusat pelayanan maupun instalasi air tidak terlalu berpengaruh karena keseluruhan lokasi masih berada di dalam area UNS, yang menandakan perbedaan jarak masih terlampau dekat. Sedangkan untuk kriteria ketersediaan lahan juga berpengaruh namun reservoir yang dibuat hanya berukuran $30 \mathrm{~m}^{3}$, sehingga lahan yang dibutuhkan tidak terlalu luas dan dapat disediakan oleh alternatif yang terpilih. Selanjutnya, tabel 3 menunjukkan hasil perhitungan untuk kriteria jarak lokasi dengan instalasi air.

Tabel 2. Bobot Setiap Alternatif Lokasi berdasarkan Jarak dengan Instalasi Air

\begin{tabular}{lcccccc}
\multicolumn{7}{c}{ Instalasi Air } \\
\hline $\begin{array}{c}\text { Jarak } \\
\text { dengan } \\
\text { instalasi } \\
\text { air }\end{array}$ & $\mathbf{1}$ & $\mathbf{2}$ & $\mathbf{3}$ & $\mathbf{4}$ & $\mathbf{5}$ & $\begin{array}{c}\text { Rata- } \\
\text { rata }\end{array}$ \\
\cline { 2 - 7 } & \multicolumn{6}{c}{ Bobot } \\
\hline $\begin{array}{l}\text { Fakultas } \\
\text { Teknik }\end{array}$ & 0.083 & 0.074 & 0.110 & 0.110 & 0.083 & 0.087 \\
\hline $\begin{array}{l}\text { Fakultas } \\
\text { Hukum }\end{array}$ & 0.503 & 0.440 & 0.409 & 0.455 & 0.422 & 0.446 \\
\hline $\begin{array}{l}\text { Fakultas } \\
\text { Pertanian }\end{array}$ & 0.134 & 0.181 & 0.175 & 0.130 & 0.189 & 0.162 \\
\hline
\end{tabular}

Dari tabel 2 tersebut diketahui bahwa Fakultas Hukum memiliki nilai bobot yang tertinggi, yaitu sebesar 0,642. Hal ini disebabkan karena Fakultas Hukum memang berada di lokasi yang paling dekat dengan lokasi SPAM UNS jika dibandingkan 2 alternatif lokasi lainnya. Selanjutnya, tabel 3 menunjukkan hasil perhitungan untuk kriteria jarak lokasi dengan pusat pelayanan.

Tabel 3. Bobot Setiap Alternatif Lokasi berdasarkan Jarak dengan Pusat Pelayanan

\begin{tabular}{|c|c|c|c|c|c|}
\hline \multirow{2}{*}{$\begin{array}{l}\text { Jarak } \\
\text { dengan } \\
\text { pusat } \\
\text { pelayanan }\end{array}$} & \multicolumn{5}{|c|}{ Bobot } \\
\hline & 1 & 2 & 3 & 4 & 5 \\
\hline $\begin{array}{l}\text { Fakultas } \\
\text { Teknik }\end{array}$ & 0.099 & 0.232 & 0.386 & 0.269 & 0.365 \\
\hline $\begin{array}{l}\text { Fakultas } \\
\text { Hukum }\end{array}$ & 0.232 & 0.099 & 0.090 & 0.118 & 0.232 \\
\hline $\begin{array}{l}\text { Fakultas } \\
\text { Pertanian }\end{array}$ & 0.365 & 0.365 & 0.246 & 0.308 & 0.099 \\
\hline
\end{tabular}

Dari tabel 3 dapat diketahui bahwa Fakultas Pertanian memiliki nilai bobot yang tertinggi, yaitu sebesar 0,398. Hal ini dikarenakan Fakultas Pertanian berada dalam zona 1 dimana jumlah fasilitas pelayanan lebih banyak dibandingkan dengan 2 alternatif lainnya, serta lokasi Fakultas Pertanian tepat berada di tengah dari area zona 1 tersebut. Selanjutnya, Tabel 4 menunjukkan hasil perhitungan untuk kriteria ketinggian tempat.

Tabel 4. Bobot Setiap Alternatif Lokasi berdasarkan Ketinggian Tempat

\begin{tabular}{lcccccc}
\hline \multirow{6}{*}{$\begin{array}{c}\text { Ketinggian } \\
\text { tempat }\end{array}$} & 1 & 2 & 3 & 4 & 5 & $\begin{array}{c}\text { Rata- } \\
\text { rata }\end{array}$ \\
\cline { 2 - 7 } & 0.130 & 0.175 & 0.080 & 0.099 & 0.140 & 0.119 \\
\hline $\begin{array}{l}\text { Fakultas } \\
\text { Teknik }\end{array}$ & 0.455 & 0.409 & 0.456 & 0.365 & 0.473 & 0.431 \\
\hline $\begin{array}{l}\text { Fakultas } \\
\text { Hukum }\end{array}$ & 0.110 & 0.110 & 0.184 & 0.232 & 0.082 & 0.144 \\
\hline $\begin{array}{l}\text { Fakultas } \\
\text { Pertanian }\end{array}$ & & & & & & \\
\hline
\end{tabular}

Dari tabel 4 dapat diketahui bahwa Fakultas Hukum memiliki nilai bobot yang tertinggi, yaitu sebesar 0,621. Hal ini dikarenakan Fakultas Hukum memang berada di lokasi tertinggi jika dibandingkan 2 alternatif lokasi lainnya. Selanjutnya, tabel 5 menunjukkan hasil perhitungan untuk kriteria ketersediaan lahan.

Tabel 5. Bobot Setiap Alternatif Lokasi berdasarkan Ketersediaan Lahan

\begin{tabular}{lcccccc}
\multicolumn{7}{c}{ Ketersediaan Lahan } \\
\hline $\begin{array}{l}\text { Ketersedi- } \\
\text { aan lahan }\end{array}$ & 1 & 2 & 3 & 4 & 5 & $\begin{array}{c}\text { Rata- } \\
\text { rata }\end{array}$ \\
\cline { 2 - 7 } & 0.181 & 0.246 & 0.440 & 0.281 & 0.197 & 0.269 \\
\hline $\begin{array}{l}\text { Fakultas } \\
\text { Teknik }\end{array}$ & 0.074 & 0.090 & 0.074 & 0.080 & 0.074 & 0.098 \\
\hline $\begin{array}{l}\text { Fakultas } \\
\text { Hukum }\end{array}$ & $0.0900 t$ & 0.386 & 0.181 & 0.333 & 0.447 & 0.357 \\
\hline $\begin{array}{l}\text { Fakultas } \\
\text { Pertanian }\end{array}$ & 0.440 & 0.357 &
\end{tabular}

Dari tabel 5 dapat diketahui bahwa Fakultas Pertanian memiliki nilai bobot yang tertinggi, yaitu sebesar 0,514. Hal ini dikarenakan Fakultas Pertanian memang memiliki ketersediaan lahan yang terluas jika dibandingkan 2 alternatif lokasi lainnya. Selanjutnya, tabel 6 menunjukkan hasil akhir perhitungan matriks dari keseluruhan kriteria.

\begin{tabular}{lc}
\multicolumn{1}{c}{ Tabel 6. Hasil Akhir Perhitungan } \\
\hline Rangking & $\begin{array}{c}\text { Bobot } \\
\text { Total }\end{array}$ \\
\hline Fakultas Hukum & 0.248 \\
\hline Fakultas Teknik & 0.176 \\
\hline Fakultas Pertanian & 0.142 \\
\hline
\end{tabular}

Beedasarkan tabel 6 dapat diketahui bahwa bobot yang paling tinggi adalah Fakultas Hukum, seĥngga lokasi ini yang akan dipilih sebagai tempat pembangunan reservoir baru. Fakultas Hukum mendapatkan nilai bobot total terbesar karena memiliki bobot terbesar juga pada prioritas kriteria yang paling utama, yaitu ketinggian tempat. 
Selain dengan penambahan investasi berupa reservoir baru, Febriany (2014) menyatakan bahwa ada beberapa program yang dapat direncanakan untuk menurunkan kebocoran, seperti pemasangan dan penggantian water meter, serta rehabilitasi dari pipa-pipa yang menjadi jaringan distribusi. Hal-hal yang sudah disebutkan dapat diterapkan bersamaan dengan pembangunan reservoir untuk memperoleh hasil yang optimal.

\subsection{Perbandingan Jumlah Kerugian Sebelum dan Setelah Usulan}

Setelah dilakukan pembangunan reservoir baru, maka dapat dianalisis perbandingan jumlah kehilangan air dan kerugian finansial antara sebelum dan setelah usulan yang berupa pembangunan reservoir tambahan dan pemasangan water meter induk. Untuk jumlah kerugian setelah adanya reservoir baru diasumsikan waktu pendeteksian dari letak kebocoran pipa hanya setengah hari dan menghasilkan kehilangan kurang lebih sebanyak 8.000 liter, hal ini dikarenakan wilayah UNS sudah dibagi menjadi 2 zona dan diusulkan pemasangan water meter induk untuk setiap aliran sehingga pelacakan letak kebocoran pipa jauh lebih mudah. Perbandingan kehilangan air dan kerugian finansial sebelum dan setelah usulan dapat dilihat pada tabel 7 .

Tabel 7. Perbandingan Kehilangan Air dan Kerugian Finansial Sebelum dan Setelah Usulan

\begin{tabular}{cccc}
\hline & Sebelum Usulan & Setelah Usulan & Selisih \\
\hline $\begin{array}{c}\text { Kehilangan } \\
\text { air (liter) }\end{array}$ & 20000 & 8000 & 12000 \\
\hline $\begin{array}{c}\text { Kehilangan } \\
\text { air } \\
\text { (presentase) }\end{array}$ & $70 \%$ & $28 \%$ & $42 \%$ \\
\hline $\begin{array}{c}\text { Kerugian } \\
\text { Finansial } \\
\text { per bulan }\end{array}$ & Rp40,000,000.00 & Rp16,000,000.00 & Rp24,000,000.00 \\
\hline
\end{tabular}

Dari tabel tersebut dapat diketahui bahwa usulan yang diberikan dapat menekan kerugian hingga sebesar Rp 24.000.000,00, sehingga usulan sangat disarankan untuk dilakukan. Namun, untuk pembangunan sebuah reservoir diperlukan pertimbangan biaya investasi yang dikeluarkan. Total biaya untuk membangun reservoir dengan volume $720 \mathrm{~m}^{3}$ berdasarkan Yudha, Qomariyah, dan Sugiyarto (2014) sementara reservoir yang ingin diusulkan untuk dibangun oleh SPAM UNS hanya bervolume $30 \mathrm{~m}^{3}$ sehingga perlu dilakukan penyesuaian perhitungan dengan teknik interpolasi dan dihasilkan total biaya yang ditunjukkan pada tabel 8 .

Tabel 8. Perhitungan Total Biaya Pembangunan Fasilitas Reservoir $30 \mathrm{~m}^{3}$

\begin{tabular}{clrr}
\hline \multirow{2}{*}{ No } & \multicolumn{1}{c}{$\begin{array}{c}\text { Uraian } \\
\text { Pekerjaan }\end{array}$} & Reservoir $720 \mathrm{~m} 3$ & Reservoir $30 \mathrm{m3}$ \\
\cline { 2 - 4 } 1 & $\begin{array}{l}\text { Pekerjaan } \\
\text { Persiapan }\end{array}$ & $4,907,694.00$ & $204,487.25$ \\
\hline 2 & Pekerjaan Tanah & $11,120,877.90$ & $463,369.91$ \\
\hline \multirow{2}{*}{3} & $\begin{array}{l}\text { Pekerjaan } \\
\text { Pasangan dan } \\
\text { Beton Bertulang }\end{array}$ & $994,783,031.55$ & $41,449,292.98$ \\
\hline 4 & $\begin{array}{l}\text { Pekerjaan } \\
\text { Plesteran }\end{array}$ & $16,269,422.40$ & $677,892.60$ \\
\hline 5 & $\begin{array}{l}\text { Pekerjaan lain- } \\
\text { lain }\end{array}$ & $30,504,050.00$ & $1,271,002.08$ \\
\hline & Total & $1,057,585,076$ & $44,066,044.83$ \\
\hline \multicolumn{3}{c}{ Sumber: (Yudha, Qomariyah, \&Sugiyarto, 2014) }
\end{tabular}

\section{Simpulan}

Berdasarkan tahapan yang dilakukan, dapat diketahui bahwa proses distribusi SPAM UNS dilakukan melalui pipa menuju 129 titik, baik water tap maupun water dispenser yang tersebar di seluruh fakultas dan gedung-gedung lainnya di UNS. Namun, dalam proses pendistribusian ini terdapat masalah yang menjadi perhatian utama bagi SPAM UNS, yaitu kebocoran pipa. Pipa yang bocor tidak dapat dideteksi letaknya sehingga memakan waktu yang lama untuk menemukan letak pipa yang bocor. Untuk mencari letaknya tersebut dapat memakan waktu hingga 2 hari sehingga kehilangan air yang dialami dapat sangat merugikan pihak SPAM UNS.

Untuk mengatasi hal tersebut, hal pertama yang dilakukan peneliti adalah menghitung jumlah kerugian finansial dalam kurun waktu sebulan dan berdasarkan pengolahan data diperoleh nominal kerugian sebesar Rp. 40.000.000,00. Walaupun sebenarnya harga dari air minum ini gratis namun apabila dialokasikan untuk produk kemasan jumlah ini bukan jumlah yang kecil. Setelah itu, dilakukan tahap identifikasi jumlah dan lokasi dari setiap water tap dan water dispenser, serta dilakukan penzonaan menggunakan konsep DMA, pembagian zona yang dilakukan cukup menjadi 2 zona saja karena cakupan wilayah UNS masih termasuk kecil untuk sistem jaringan distribusi air. Hasil dari penzonaan ini adalah usulan pembangunan reservoir baru dan pemasangan water meter induk aliran sehingga peninjauan kebocoran pipa lebih mudah dilakukan. Untuk melakukan pembangunan reservoir baru, kemudian diperlukan penetuan lokasi pembangunan. Penentuan lokasi pembangunan dilakukan dengan menggunakan metode AHP karena ada beberapa kriteria yang harus dipertimbangkan. Dari hasil penggunaan metode AHP diperoleh Fakultas Hukum sebagia lokasi untuk penempatan reservoir baru karena memiliki nilai bobot akhir terbesar, yaitu 0,477. Dan yang terakhir adalah membandingkan antara kerugian finansial sebelum dan setelah dilakukan usulan. 
Dari hasil pengolahan data diperoleh bahwa kerugian finansial yang sekarang bernilai lebih kecil, yaitu Rp. 16.000.000,00 dengan selisih sebesar Rp. 24.000.000,00. Namun, sebagai bahan pertimbangan, peneliti juga menghitung kemungkinan total biaya yang dikeluarkan untuk membuat reservoir baru dengan hasilnya adalah sebesar Rp 44.066.044,83. Sehingga dapat disimpulkan bahwa pembuatan reservoir baru layak karena nilai pembuatan hampir sama dengan nilai kerugian awal yang dialami oleh jaringan distribusi SPAM UNS.

\section{Daftar Referensi}

Andayani, R., Firda, A., \&Permatasari, R. (2019). Analisis Kehilangan Fisik Dan Tingkat Kepuasan Pelanggan Pada DMA Unit 3 Ilir Pdam Tirta Musi Palembang. Jurnal Teknik Sipil UNPAL Vol.9, No.1, 1-14.

BSN. (2011). Tata cara perencanaan teknik jaringan distribusi dan unit pelayanan sistem penyediaan air minum. Retrieved from Sistem Informasi Manajemen Standard: http://sni.litbang.pu.go.id

El Ahmady, I. I., \&Emenda, S. (2014). Pemilihan Program Pengendalian Kehilangan Air Serta Pengaruh Implementasinya Terhadap Peningkatan Pendapatan PDAM. Jurnal Tenik Lingkungan, 142-151.

Fatchurahman, M. (2016). Implementasi Metode AHP Untuk Menentukan Lokasi Distribusi Air Mineral.Kediri: UN PGRI Kediri.

Febriany, I. E. (2014). Strategi Penurunan Kebocoran Di Sistem Distribusi Air Bersih Kota Mataram.Surabaya: Institu Teknologi Sepuluh Nopember.

Kusumajati, B., Solichin, \& Koosdayani. (2016). Analisis Distribusi Air pada Sistem Penyediaan Air Minum Kampus Universitas Sebelas Maret dengan Epanet. e-Jurnal Matriks Teknik Sipil, 806-813.

PDAM. (2012). Laporan Teknik. Mataram.

PUPR. (2018). Modul 8 Distrik Meter Area (DMA). Direktorat Jenderal Cipta Karya.

Puspitasari, I., \& Purnomo, A. (2017). Studi Kehilangan Air Komersial (Studi Kasus: PDAM Kota KendariCabang Pohara). Surabaya: Jurnal Teknik ITS Vol. 6, No. 2.

Siregar, N. A., \& Mulia, A. P. (2013). Evaluasi Kehilangan Air (Water Losses) PDAM TirtanadiPadangsidimpuan Di Kecamatan Padangsidimpuan Selatan. Medan: Universitas Sumatera Utara.

Thornton. (2008). Penurunan Kehilangan Air. Semarang.

Walangare, D., Delima, R., \&Restyandito. (2012). Sistem Prediksi Pertandinga Sepak Bola dengan Metode Analytical Hierarchy Process (AHP). Informatika Vo. 8 No.2, 181-188.

Yudha, G. L., Qomariyah, S., \&Sugiyarto. (2014). Studi Kelayakan Penyediaan Air Minum Kota Surakarta Planning Horizon 10 Tahun (Studi Kasus : PDAM Kota Surakarta). eJurnal Matriks Teknik Sipil, 860-865. 
Lampiran 1. Pembagian Zona Reservoir Pelayanan




Lampiran 2. Struktur Hierarki AHP Lokasi Pembangunan Reservoir

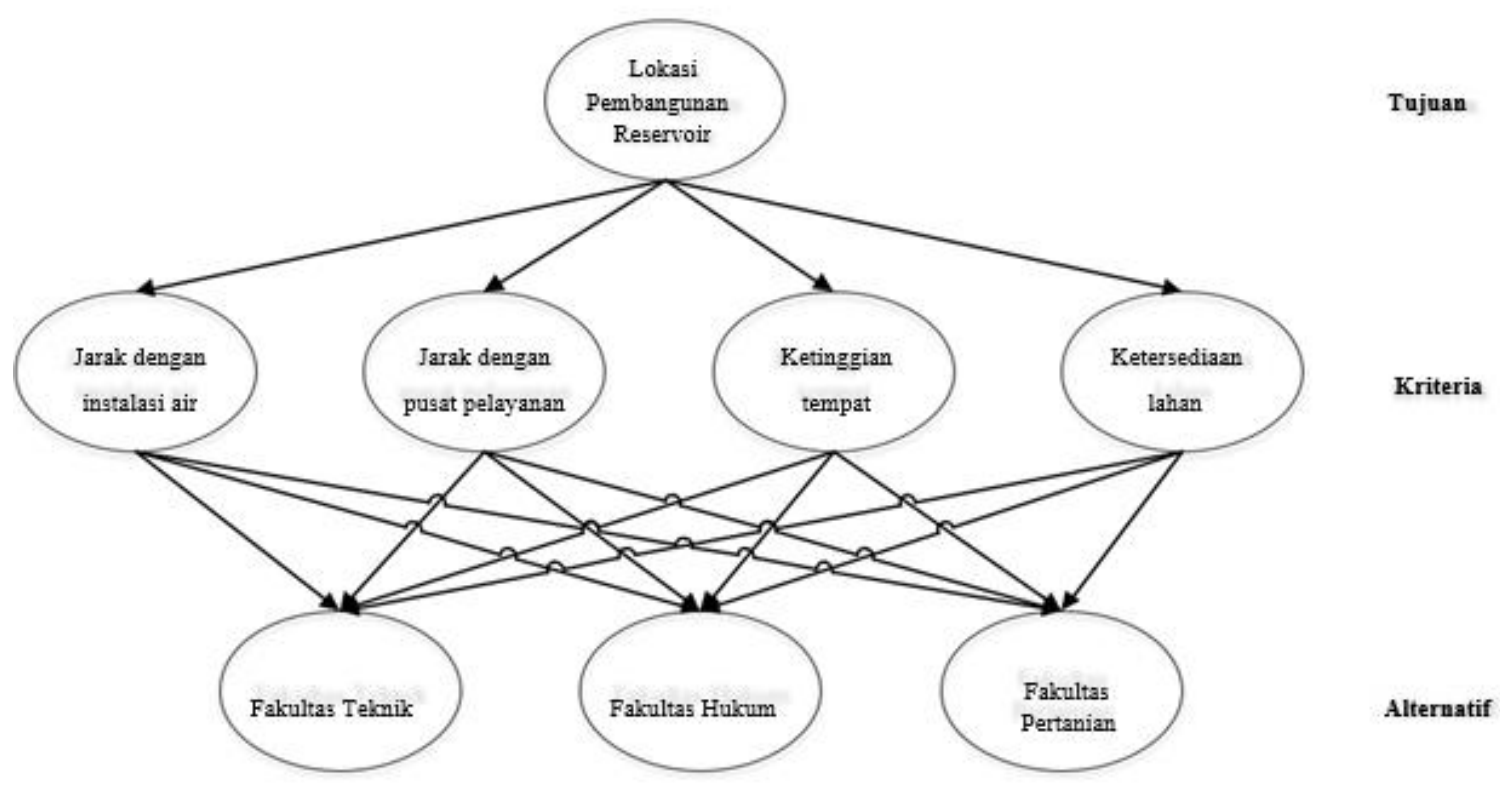

